\title{
WHATSPEAK: Audiovisual Digital Assessment in Enhancing Confident and Independent Speaking Skills
}

\author{
Pavitthra Arulchelvan ${ }^{1}$, Melor Md Yunus ${ }^{2, *}$ \\ ${ }^{1}$ SJKT Ladang Blue Valley, Malaysia \\ ${ }^{2}$ Faculty of Education, Universiti Kebangsaan Malaysia, Malaysia
}

Received February 29, 2020; Revised May 12, 2020; Accepted May 20, 2020

Copyright $(2020$ by authors, all rights reserved. Authors agree that this article remains permanently open access under the terms of the Creative Commons Attribution License 4.0 International License

\begin{abstract}
Fluent speaking skills in English are considered major requirements in the growth of universal civilization as the fluency of spoken words allow a person to be well understood in the designated area. Learners are expected to forward ideas confidently and independently. However, they faced challenges in managing simple English communication among their circle. Therefore, the implementation of WhatsApp based audiovisual tasks were infused action research to enhance learners' speaking skills. The research was conducted among learners aged eight in a rural primary school in the district of Cameron Highlands, Pahang, Malaysia. Results were collected from pre-test and post-test, observation and survey. Data revealed that learners were involved actively in collaborative speaking sessions by exchanging ideas confidently and independently. Significantly, their spoken Performance Level improved as they began to socialize and prompt proper language usage in the interactions through the aid of pictures, videos and audios. Researchers had suggested the incorporation of genuine learning and assessment of speaking skills via WhatsApp based audiovisual materials as an effective effort in eventually producing confident and independent English speakers.
\end{abstract}

Keywords WhatsApp, Audiovisual Tasks, Speaking Assessment, Collaborative Learning, Confident Speakers, Independent Speakers

\section{Introduction}

In developing nations, skilled literacy abilities and instructional opportunities are essential because information will enable kids to have a brighter future and eradicate poverty. Due to that, comprehensible speaking can meet daily undertakings with great maturity. English language usage in multinationals such as Hong Kong and Kuala Lumpur shows that spoken forms have been found to be essential for efficient communication towards global customers [35, 53].

However, speaking competence is difficult especially for a country like Malaysia that does not use English as its mother language, the students are having low competency [36] in using English. Generally, in non-English country, the English proficiency was low due to the non-English languages used in society.

There are other influencing variables besides the absence of use of English in daily communication [30]. From the view of the most educators and learners, English is seen only as a topic of primary school and the significance of English is not acknowledged for work and real communication purposes [36].

Also, in the national-type primary schools, only 150 minutes are allocated for English in a week [40]. Compared to their mother-tongue languages which have been given 360 minutes per week, the chances for teachers to meet pupils during English lessons are rather lesser and limited $[8,9]$. Due to this scenario, skills such reading and writing are given much importance in order to equip pupils with the need to answer examinations. Therefore, the speaking skills are much neglected because if teachers were to observe each pupil's spoken competence individually, it will consume more duration. As a result, they would be unable to complete their textbook syllabus and topics before schooling semester ends.

Presently, it has becoming crucial that learners are equipped with the required speaking skills [39] thus, they can maintain the flow of the quickly rising international economy as shown in the $2013-2025$ Malaysia Education Blueprint. The Blueprint also clearly states the prominence of curriculum and assessment production in the practice of the 21 st Century classrooms. In addition, according to the Blueprint record, each learner must have proficient independent English skills as described by the Common European Framework of Reference (CEFR) [37, 35].

Collaborative effort thus has been cultivated between the 
Ministry of Education, Malaysia and Cambridge English, United Kingdom (CE) to enable the construction of the English Language Curriculum (SBELC) based on standards. The SBELC document includes a description of the English Language Content and Learning Standards [40] and aligned educational alternatives to the CEFR.

Furthermore, the CEFR levels and descriptors are the foundation for the implementation of curriculum standards for pre-school, primary and secondary schools. The SBELC document contains the syllabus that contains key components of a lesson, namely themes, topics, content and learning standards, cross curricular elements, differentiation strategies and evaluation standards.

The structure also serves as a reference for developing the target skill levels of the SBELC (A1 and A2 as Basic User; B1 and B2 as Independent User; and $\mathrm{C} 1$ and $\mathrm{C} 2$ as Proficient User). These curricula specified levels describe what the learners are expected to attain at every stage of learning from preschool, elementary to Form Five $[36,40]$.

It seeks to equip students with basic language abilities to allow them to efficiently interact in a multitude of situations suitable to the level of growth of the learners. All language capacities should then be evaluated using relevant assessment instruments [28].

Teachers are responsible for gaining immediate feedback [52] on the learning performance of their students and providing them with instant feedback so that they can change their teaching by altering their techniques $[2,18,32]$ to further enhance individual pupil's performance in the classroom.

Thus, formative evaluation is performed as an ongoing process during the teaching and learning phase in the schools. The achievement rates of learners are registered and reported every quarterly through this. Different evaluation techniques such as checklists, observations, oral presentations, quizzes, questions and answers, assignment sheets or written assignments can be used to track the accomplishment of learning standards [52]. By enforcing this system, teachers can build a profile of the language development of their learners through an ongoing evaluation.

One of the ways to develop learners' English-speaking competence is by doing on going assessments in and out of classrooms. Assessments in Malaysian classrooms basically take the form of summative in which students are required to sit for paper-based exams to test their reading and written skills $[20,2]$. However, the speaking skills are left out in the assessment part due to absence of proper speaking assessment tools and lack of attention towards it $[37,42]$.

At this point, the integration of ICT in education in terms of social media had been in implementation for the past few years. It is believed to improve learners' communication skills and knowledge input. Especially, WhatsApp as one of the leading social media apps used by billions of active users is being infused in the process of learning $[43,61,62]$. As found by [14] students having access to smart phones and Internet facilities show high interest in participating in technology-based activities by sharing ideas, collaborating to solve tasks and discussing latest happenings $[1,41]$.

It embodies the notion of encouraging learners to build their learning process, enhancing their knowledge, applying language skills, and communicating with their members in collaboration [8]. Here, educators can involve their students in the process of reciprocal communication and meaningful discussion $[1,11)$ by offering them appropriate possibilities to interact and assert themselves to overcome their speaking struggles.

Within the space of communication, words, gestures, sounds and visuals, the never-ending process between the learners and the environment encourage for sharing meaningful information virtually [28, 31, 42]. All they need is a prompt from teacher or a fellow peer to involve deeply in the discussion of the subject matter. When the right knowledge is shared instantly among members, it positively influences learners in the group to collaborate actively so they will be able to contribute equally regarding the topic [16, 47, 42].

The first move was done by prompting learners with pictures stimulus and question regarding it in the form of audio. Secondly, they were given recorded videos to be watched and answered. The final cycle was the use of independent audios as stimulators. All their queries, responses and feedback reached through video and audio messages which captured the attention of teacher and other learners to view, listen and share their opinions. The cycles went in hand with the speaking assessment process which was conducted smoothly. If learners found their responses to be less efficient through the performance indicator given by teacher, they submitted their improvised version of audio messages again. The new content was viewed and listened by teacher and friends for further discussion and assessment.

Students' engagement in WhatsApp groups promoted their participation in spontaneous discussions and raised their self-confidence $[8,40,61,62]$. Results by $[3,44]$ found that, integrating and implementing mobile technology through WhatsApp assisted learners develop a learning community, and in exchange, learners build and share understanding through instant messaging with other group members. In this respect, several studies by [10, 29, $55,62]$ supported activities with technological assistance to boost students' motivation to speak in English.

Findings by $[21,6,15,62]$ concluded that the usage of voice message chat on WhatsApp was an efficient method for improving verbal communication between learners. It also produced a suitable platform for learners to practice language verbally well outside of school environments for what they have learned in the context of the classroom. In addition, the respondents expressed their consent and demonstrated favorable attitudes towards it.

As they cooperate with one another, group activities facilitate confident language learning process $[60,52]$. 
Confident speakers influenced their group members to respond actively towards stimulus [33, 42]. Through collaborative learning, their words and speaking structures were imitated frequently [49]. In the speaking tasks, learners focused on speaking and they spoke freely among themselves about the content and topics based on daily routines and experiences.

Digitalized speaking activities [27] help learners to manage their time and involve in the tasks independently. They are allowed to respond at their own pace thus having enough freedom and time to come up with ideas. These learners portray advanced skills in looking for information, reflect upon prior knowledge and gathering necessary details to share with their peers [38]. Also, based on perceived responses, they attempt courageously in asking questions for clarity. When their friends are lacking in responding appropriately, independent learners always lend them with required assistance by providing them with the clues, phrases, ideas and model exemplar language for better speaking in English [25].

Moreover, appreciating friends for their contributions and motivating them with positive words and non-verbal responses $[4,51,56]$ are other characteristics inhibited by them. They constantly replied to their friends' doubts while paying attention at their discussions. Errors found in their spoken sessions would be given immediate comments together with constructive feedback to acknowledge their work and set opportunities to further develop and enhance their speaking skills $[5,9,62]$.

Thus, this paper aims to explore effectiveness and insights of WhatsApp based audiovisual tasks in developing learners' speaking skills Performance Level (PL). It also intends to identify the impact of WhatsApp aided collaborative activity in promoting confident and independent speaking learners. In this research, audiovisual materials refer to the learning aids such as pictures, video and audio. While the tasks follow questioning and answering via spoken responds towards the audiovisual aids. Self-study using the WhatsApp tasks might be an advantage for advance learners. However, including learners of beginners, intermediate and advance levels in this research prompts for the tasks to be done as group collaborations. As they discuss and assist each other, learning becomes more meaningful to motivate and enhance speaking.

\section{Methodology}

The action research [19] involved 8 primary respondents aged eight from the primary school located in the deep rural demographic region of Cameron Highlands in the state of Pahang. Due to less population in the region, the class sizes were relatively small, containing limited number of pupils. The 8 years old respondents consisted of mixed levels in their spoken skills. Despite their average language ability, they were keen in exercising social media for learning betterment. Through the action research cycles, they responded to pictures (1st cycle), videos (2nd cycle) and audio prompts (3rd cycle) by speaking ideas, throwing questions and providing feedback to others via audio messages in WhatsApp messenger. Based on instant assessment, Performance Level and teacher's corrective feedback, learners attempted to extend their discussion and interacted collaboratively in the virtual WhatsApp group.

Their pre-test and post-test Performance Level were compared to identify valid percentage scores of each item. Respondents then answered simple survey questionnaires on personal experiences and Performance Level Descriptors. Photographs of classroom group speaking activities and the events were observed and described according to their interest, motivation, presence, collaboration and overall improvement as well as achievements. The results were further discussed to draw conclusions.

\section{Findings and Discussion}

Table 1. Pre-Test and Post-Test PL Scores

\begin{tabular}{|c|c|c|c|c|}
\hline \multicolumn{5}{|c|}{ Task: Describe about today's weather. How would you like the weather to be? Why? } \\
Duration: 3-5 minutes
\end{tabular}


Table 1 displays the pre-test and post-test PL scores of participants. The task given instructed them to describe the weather of the particular day. They also justified and reasoned either they liked the weather or not.

Post-test results in Table 3 showed four participants scored PL of 6/6. To reach the highest benchmark, they have participated and performed utmost effort in the audiovisual tasks in becoming confident and independent speakers. Interestingly, they have got ideas beyond the audiovisual materials posted and described it based on prior knowledge [25, 34, 44]. Together, they performed various gestures and facial expressions [56] during the spoken interaction. It further supported them in delivering the ideas confidently. They diligently looked for new vocab to use them in the right tense while speaking. Thus, they exceeded the expectations of target language skills [39] by inspiring and guiding the intermediate and low achieving peers to follow their steps as well.

Highly motivated by the advance learners, two beginners started to show improvement in their post-test PL scores of achieving 5/6. They were on track to exceed expectations of target skills which made them confident speakers. It clearly demonstrated the significance of boosting self-confidence $[33,54]$ that merely enabled them to speak the content in flow. They did not worry about making mistakes [38] since they were constantly provided with corrective feedback by teacher and friends. So, they confidently uttered sentences and gained better remarks though their sustained minimal errors.

Despite being reluctant speakers during the pre-test scoring, two participants gradually developed themselves in gaining 4/6 and 3/6 respectively. One of them was identified as working towards exceeding expectations of target skills and another achieved basic expectation of target skills. The intermediate learner was able to perceive and connect the ideas. She was continuously trying to overcome fear $[55,40]$ by imitating the model language used by peers to deliver her description. Again, her self-reliance and motivation [3,20] played utmost role in intensifying the speaking skills.

After receiving a lot of guidance and feedback from teacher and peers, the novice learner managed to perform in the post-test with basic speaking skills. His humorous and hyper learning styles were encouraged and infused into the speaking sessions to further motivate him to speak naturally in the target language [46]. Though he began the descriptions with limited vocabulary and mostly incomplete sentences, he soon picked up some new words and copied the phrases from his friends' discussions [27, 47, $3,51,59]$. Over time and language exploration during the audiovisual interactions, he was able to participate and manage discussions fairly $[3,8,25,41]$.

Table 2 shows the gradual improvement of the learners' speaking skills Performance Level from 2 to 6 throughout the involvement in picture, video, audio and group speaking tasks. During the picture performance, pupils merely scored PL 2 where they responded to questions asked by others in the group chat. Their descriptions were minimal and basically revolved about the food, features and actions of a caterpillar. Though they used suitable verbs to describe, the sentences were less structured with tense errors.

Table 2. WhatsApp Audiovisual Performance Cycle

\begin{tabular}{|c|c|c|c|}
\hline $\begin{array}{c}\text { Picture } \\
\text { Performance }\end{array}$ & Video performance & Audio Performance & Classroom Group Speaking Task \\
\hline $\begin{array}{c}\text { PL 2 } \\
\text { Minimal basic } \\
\text { description } \\
\text { Express emotions } \\
\text { Appropriate verb } \\
\text { used } \\
\text { Less structured } \\
\text { sentences } \\
\text { Ask and respond to } \\
\text { question } \\
\text { Respond to } \\
\text { question }\end{array}$ & $\begin{array}{c}\text { PL } 4 \\
\text { Address a friend to ask or } \\
\text { respond } \\
\text { Express emotions } \\
\text { More structured questions and } \\
\text { descriptions } \\
\text { Use some new vocab to } \\
\text { explain with examples } \\
\text { Provide suggestions } \\
\text { confidently } \\
\text { Predict happenings } \\
\text { Describe based on previous } \\
\text { knowledge and own } \\
\text { experiences }\end{array}$ & $\begin{array}{c}\text { PL } 5 \\
\text { Narrative description } \\
\text { Link between content } \\
\text { Futuristic thinking } \\
\text { Self-reflection through } \\
\text { questioning } \\
\text { Provide explanation with } \\
\text { justification confidently } \\
\text { Ask for opinion } \\
\text { Explanation well justified } \\
\text { Ask and respond to a friend } \\
\text { Request for clarification } \\
\text { Includes suggestions } \\
\text { Wide vocab power } \\
\text { Lengthy and structured } \\
\text { sentences } \\
\text { Speak confidently based on } \\
\text { prior knowledge and } \\
\text { experiences }\end{array}$ & $\begin{array}{c}\text { PL 6 } \\
\text { Matured arguments } \\
\text { Collaborative and fun interactions } \\
\text { Provide corrective feedback } \\
\text { Humble communication } \\
\text { Voice opinions confidently } \\
\text { Begin conversation independently } \\
\text { Wide vocab power } \\
\text { Use moderate and lengthy sentences } \\
\text { Smooth flow in discussion } \\
\text { Think beyond what's in pictures } \\
\text { Express emotions } \\
\text { Relate content with prior knowledge and } \\
\text { experiences } \\
\text { Accept or decline ideas politely } \\
\text { Guide and assist the beginners to speak their } \\
\text { mind } \\
\text { Two-way interaction with teacher to clear } \\
\text { doubts } \\
\text { Minimal grammatical errors }\end{array}$ \\
\hline
\end{tabular}


Observation revealed that all respondents spoke their mind in short exchanges and simple sentences. Beginners usually pertain certain anxiety $[51,55,40]$ during speaking tasks. Due to overwhelming nervousness, learners tend to make mistakes and take them seriously. Hence, such discomfort moments hinder their speaking skills [20, 44]. Moreover, they could only describe pictures with limited examples. The identified issues were caused by pupils' low vocab power and they rely on fixed phrases to create questions [45]. Being afraid to begin the discussion, they appear as dependent language learners.

However, video performance cycle highlighted the use of appropriate question tags and creativity in using the phrases and vocab to ask and respond in the group $[23,58$, 44]. Learners scored PL 4 during the session. When questions hit the target group correctly, they understand the requirements and ease discussion. Besides, they addressed friends politely during discussion and explained whom the question or respond was referred to so, they get the intended reply instantly [50]. Also, pupils agreed to statements produced by peers by describing visible and invisible details from the video stimulus [14]. As pupils could explain the abstract content, it stimulated their imaginative skills to think and predict happenings.

Significantly, their prior knowledge and experiences promoted confident speaking environment $[5,52]$. More structured descriptions were delivered using new vocab. It showed that pupils enthusiastically found more words to be involved in the task. Furthermore, attaching emoticons together with audio messages enhanced understanding of vocab and motivated continuous participation [10]. Supportive peers also provided suggestions and feedback confidently $[9,20]$ as pathed way for improvement in speaking the content in right way. Hence, pupils contribute various opinions by having the right words, content and platform to speak.

Moreover, in the audio performance, learners achieved PL 5. pupils were still working on track to achieve and exceed target of expectation of the speaking skills [39] Sharing details through structured sentences made them to minimize grammatical errors. As their maturity increased, they reflected upon their prior knowledge and experiences to illustrate information through narrative descriptions [51]. It showed their creativity in using the language to produce speech and further explain with justifications in order to fulfill task requirements. As can be viewed clearly, they have been upgrading themselves at each cycle [2]. They improved from short exchanges to moderate and lengthy descriptions while unstructured tenses and verbs became more structured. Use of wide vocab power and emoticons too contributed to smooth flow between content delivery thus enabled confident speaking zone whereby questions and answers appeared in the right sequence [48]. Importantly, their request for clarification from peers [60] considering pictures and feedback were presented through positive arguments. It boosted them to stand genuinely on their points and seek for better understanding.

During the classroom speaking activities (PL 6), pupils were made to hear all the audio messages gathered during the WhatsApp tasks. Hearing their own voices together with peers' responses put them into the feeling of being acknowledged for their contributions [30, 36]. Such recognition inspired the learners to involve actively in the classroom speaking tasks and react to the stimulus given. They showed more concern towards giving feedback and making corrections. Even the low achievers were highly motivated to collaborate confidently with their peers [24, $25]$ in ensuring to produce quality speaking outputs. They were made possible through continuous speaking collaborations $[8,15,46]$ by implementing various picture, video and audio materials.

It was noted that the respondents voiced opinions confidently and began to comprehend independently. They had fun interacting in accepting or declining ideas politely, addressed friends humbly and felt free to choose ideas to speak. Findings revealed pupils' mastery of new and high frequency vocabulary [2]. in terms of describing the materials gathered. When they had the right amount of vocab, learners spoke confidently and independently without having the fear or worry of making errors $[26,4,54]$ It further complied them in creating questions and answering straightforward and indirect content by using suitable phrases and sentences.

Group collaboration also activated their thinking outside of box skills to naturally forward ideas beyond the pictures and videos $[22,31,8]$. Like they asked about how it felt when someone touched a snail. So, one of them replied it felt like jelly and another said it was like slime. Those responds were made either based on their prior knowledge or by relating to the texture of insect seen in the picture and video. As pupils stimulated their thinking beyond skills, they willingly connected ideas and built inner confidence to speak out [62].

Having such opportunities to discover their knowledge widely, it was pleasant to evident the way the advance speakers assisted the beginners to continue the communication [43, 34]. They guided and employed them well by giving hints, clues, words, phrases and corrective feedback to modify the errors made. It was a beneficial learning process for all the pupils that they moved as a team to work and achieve the expectations in the target $[3,8,34]$. Trying to make ends meet up, teacher's involvement as a facilitator further polished their skills by holding a two-way interaction [16]. Arising doubts in the sentence patterns and right usage of vocab were often cleared by the teacher. At urge circumstances, teacher offered guidance and feedback to the pupils. Providing immediate replies to their questions, communicating through non-verbal responses and by interrupting whenever necessary, teacher continued to boost them in presenting their minds through worthy discussions $[7,21,51,56]$. 
Table 3. Personal Experiences and Performance Level Achievement

\begin{tabular}{|c|c|c|c|}
\hline Num & Item & $\begin{array}{l}\text { Agree } \\
(\%)\end{array}$ & $\begin{array}{c}\text { Not agree } \\
(\%)\end{array}$ \\
\hline 1 & $\begin{array}{l}\text { I am interested in the speaking } \\
\text { activities. }\end{array}$ & 100 & 0 \\
\hline 2 & I enjoy sending audio messages. & 100 & 0 \\
\hline 3 & $\begin{array}{c}\text { I listen to my friends' audio } \\
\text { messages. }\end{array}$ & 100 & 0 \\
\hline 4 & I respond to my friends. & 100 & 0 \\
\hline 5 & $\begin{array}{l}\text { I feel motivated taking part in the } \\
\text { speaking activities. }\end{array}$ & 100 & 0 \\
\hline 6 & I feel confident to speak my ideas. & 100 & 0 \\
\hline 7 & Friends encourage me to speak. & 100 & 0 \\
\hline 8 & $\begin{array}{l}\text { I like the pictures, videos and } \\
\text { audios posted by my teacher. }\end{array}$ & 100 & 0 \\
\hline 9 & $\begin{array}{l}\text { Teacher and friends' feedback } \\
\text { improve my speaking skills. }\end{array}$ & 100 & 0 \\
\hline 10 & $\begin{array}{l}\text { I will continue to use WhatsApp } \\
\text { to improve my speaking skills. }\end{array}$ & 100 & 0 \\
\hline 11 & $\begin{array}{l}\text { Give simple information with } \\
\text { support. }\end{array}$ & 100 & 0 \\
\hline 12 & $\begin{array}{l}\text { Ask and answer questions with } \\
\text { support. }\end{array}$ & 100 & 0 \\
\hline 13 & $\begin{array}{l}\text { Participate in the discussions with } \\
\text { support. }\end{array}$ & 100 & 0 \\
\hline 14 & $\begin{array}{c}\text { Give simple information } \\
\text { confidently. }\end{array}$ & 100 & 0 \\
\hline 15 & $\begin{array}{l}\text { Ask and answer questions } \\
\text { confidently. }\end{array}$ & 100 & 0 \\
\hline 16 & $\begin{array}{l}\text { Participate in the discussions } \\
\text { confidently. }\end{array}$ & 100 & 0 \\
\hline 17 & $\begin{array}{c}\text { Give simple information } \\
\text { confidently and independently. }\end{array}$ & 100 & 0 \\
\hline 18 & $\begin{array}{l}\text { Ask and answer questions with } \\
\text { great confidence. }\end{array}$ & 75 & 25 \\
\hline 19 & $\begin{array}{l}\text { Participate in the discussions } \\
\text { independently. }\end{array}$ & 100 & 0 \\
\hline 20 & $\begin{array}{l}\text { Be an example to others on using } \\
\text { language. }\end{array}$ & 75 & 25 \\
\hline
\end{tabular}

Survey results displayed as in Table 3 show the personal experiences and performance level achievement of the participants in the WhatsApp based speaking assessment activities. Overall, they agreed $100 \%$ to 18 items listed in the table.

The audiovisual tasks played prominent role in assessing Year 2 pupils' speaking skills. When they presented themselves virtually in the WhatsApp group, it allowed them to observe the materials posted together with their friends' audio responds. After hearing the responses, they were motivated to send their own description about the stimulus given. Once they received the feedback of PL scores and error correction, it boosted self-confidence to extend their discussion $[12,33]$. This evidenced the tasks of picture, video and audio performances had repeated cycles of various stimulus, collaborations and feedback sessions thus allowing room for improving their speaking at every stage $[5,26,53]$. Being sustained deeply in the tasks, learners enjoyed sharing and receiving information from peers, hence intensified their efforts in contributing ideas to become better speakers of the language.
From the analysis, it was clearly seen that majority of the pupils performed the speaking skills requirements with gradual improvement $[57,8,31]$ With support from peers and teacher, they could move to the next stage in gaining self-confidence [5] and later becoming more independent [13] in contributing in the discussions. The process of speaking assessment moved from simple to complex, whereby with guidance and assistance, learners sooner showed maturity by beginning a conversation, developing it with more ideas, thinking beyond the stimulus and standing on their points firmly $[40,6,32]$.

The whole speaking assessment process via WhatsApp audiovisual tasks developed confidence in speakers. Learners were given complete autonomy to speak their mind therefore they used it as the right platform to voice their opinions. Since there were no restrictions made on what they should speak, they felt free to share ideas [13]. At first, they began with simple terms. Then, they gradually gained self-esteem [4] to speak more phrases and sentences. Freedom to speak usually tempts young learners to converse everything they have in mind. When teachers and peers shape their thinking into structured utterances, they get to know what was right and wrong. Therefore, from peer feedback and error correction, they developed confidence to speak courageously $[9,38]$.

Independent learners counted every small discovery into learning. Therefore, they valued information and delivered them into speech explicitly [38]. They were also able to reflect upon their peers' speech and played significant role in attributing constructive feedback expressively. Being problem focused and specific, they talked about the situation which needed correction. They gave praises to their peers to motivate them to do better [13]. Constructive feedback has been proposed to enhance learning in educational setting, therefore, intensifying everyone's role in performing their best in learning and transforming what they had learnt confidently and independently $[42,52]$.

To overcome certain limitation identified in this paper, pupils can be exposed to the topics much earlier in the classroom $[17,39,26]$. It can be done on weekly basis by varying the stimulus and allowing frequent group speaking activity. In that way, they could cooperatively look for the new vocab, share and take notes, rehearse the speaking sessions to model proper usage of fixed phrases and sentence structures.

Instructors could highlight the possible outcome by integrating the WhatsApp audiovisual tasks among learners of various levels. Opportunities that allow learners of different ability to work together often assist pupils to think wisely and comprehend stimulus well $[33,37]$. The assessment process would ease collaborative speaking by developing new knowledge into teaching-learning experiences to improve educational practices $[3,8]$.

Also, due to the limited number of participants at the rural school, the findings may be generalized for similar area learners with lower and intermediate English 
proficiency levels. In the interest of carrying out the research at a wider scale of lower, intermediate and advance learners, researcher could prefer employing a control group and interview methods to gather validated findings.

Teachers can utilize their WhatsApp messenger as an in-class speaking activity by including learners to record and submit their audio files. While for the beginners, they can be provided with fixed phrases learnt in the previous lessons to begin conversation and prompt to speak independently. They need a lot of support and guidance, so assisting them patiently by following together with their pace could ease the flow of moving from simple to complex. It will ensure a feasible English-speaking environment for primary learners.

\section{Conclusions}

The integration of WhatsApp based audiovisual tasks simplified the speaking assessment process of the primary learners' performance level. It was achievable due to high commitment presented by learners towards making efforts in responding at every performance cycle. Learners collaborated in fun learning environment by posting their audio messages. They excitedly responded to the questions asked in the group messenger. Gradual progress was observed at every cycle of picture, video and audio performances. It crafted a wisely planned pathway towards developing confident and independent speaking learners. The speaking assessment process is highly encouraged for educators in the English language departments to implement and gain utmost benefits in producing knowledgeable speaking community in-line to the CEFR performance level standards. Overall, the research has crucial impact on developing confident and independent speaking skills through audiovisual materials supported by the feedback sessions.

\section{Acknowledgments}

This research was supported by the grant from the Faculty of Education, University Kebangsaan Malaysia GG-2018-001 and GG-2019-009.

\section{REFERENCES}

[1] Aakash, S. (2018). An Overview on the Reciprocal Determinism Concept with Examples.

[2] Abdullah, M.Y., Hussin, S., Ismail, K. (2019). Implementation of Flipped Classroom Model and Its Effectiveness on English Speaking Performance. UKM. International Journal of Emerging Technologies in Learning, 14(9), 130-147.
[3] Agnes, K.H., Olga, V. (2018). Mobile collaborative language learning: State of the art. British Journal of Educational Technology, 49(2), 207-218.

[4] Ali, S., Khan, G.Z., Amin, I. (2019). Poetry Guided Speaking and Motivation in English as a Second Language Classroom. Pakistan Journal of Social Sciences, 39(3), 879-886.

[5] Amalia, Y. (2019). The Effectiveness of Using Drilling Technique on Students' Mastery of Expressions In Speaking Class at the First Grade of Mts Al-Huda Bandung.

[6] Amira, A.M. (2018). The Effect of WhatsApp Chat Group in Enhancing EFL Learners' Verbal Interaction outside Classroom Contexts. English Language Teaching, 11(3), $1-7$.

[7] Answer, S.A. (2015). Smartphones Wandering At the Mall: A Case Study Investigating the Use of Smartphones on English Oral Learning Skills in a Collaborative Mobile-Assisted Language Learning Environment. Northern Illinois University.

[8] Arulchelvan, P., Veramuthu, P., Singh, P. K. P., Yunus, M. M. (2019). iGen Digital Learners: Let's Collaborate via Coggle. Universiti Kebangsaan Malaysia. Creative Education, 10, 178-189.

[9] Arulchelvan, P., Yunus, M.M., Suliman, A. (2019). Social media usage among English language learners in Primary School. Revista de Ciencias Sociales y Humanidades, 4(20), $97-103$.

[10] Atkin, K. (2015). Communicate with confidence: a practical guide. Dental Nursing, 8(9), 510-513.

[11] Azlan, N. A. B., Zakaria, S. B., Yunus, M. M. (2019). Integrative Task-Based Learning: Developing Speaking Skill and Increase Motivation via Instagram. UKM. International Journal of Academic Research in Business and Social Sciences, 9(1), 620-636.

[12] Bandura, A. (1978). The Self System in Reciprocal Determinism. American Psychologist. Stanford University. 344-358.

[13] Barhoumi, C. (2015). The Effectiveness of WhatsApp Mobile Learning Activities Guided by Activity Theory on Students' Knowledge Management. Contemporary Educational Technology, 6(3), 221-238.

[14] Beebe, S.A., Beebe, S.J. (2019). Public Speaking Handbook. Pearson Education.

[15] Bharath, N., Mohan, K. (2019). Emerging trends in language learning through Comics, Games and TV series. IJELLH, $7(2), 878-885$.

[16] Bilge, C.A., Yafes, C. (2019). The Effect of "Whatsapp" Usage on the Attitudes of Students toward English Self-Efficacy and English Courses in Foreign Language Education outside the School. IEJEE, 11(3), 247-256.

[17] Bouhnik, D., Deshen, M. (2014). WhatsApp goes to school: Mobile instant messaging between teachers and students. Journal of Information Technology Education Research, 13, 217-231.

[18] Brown H.D. (2000). Teaching by Principles an Interactive Approach to Language Pedagogy. Second Edition, 491. 
[19] Carr, W.S., Kemmis, S.R (1986). Becoming critical: Education, knowledge and action research. London: Falmer Press.

[20] Cigdem, A.K., Seda, G. (2019). English Teachers' Problems Encountered in Teaching Four Basic Language Skills. International Education Studies, 12(4), 118-127.

[21] Daud, A., Ras, F., Novitri., Audia, C.P. (2019). Factors Contributing to Speaking Anxiety: A Case Study of PreService English Teachers. Journal of Educational Sciences, 3(3), 412-422.

[22] De Wilde, V., Brysbaert, M., Eyckmans, J. (2019). Learning English through out-of-school exposure. Which levels of language proficiency are attained and which types of input are important? Bilingualism: Language and Cognition, 1-15.

[23] Ding, A.E., Ottenbreit-Leftwich, A., Lu, Y.H., Glazewski, K. (2019.) EFL Teachers' Pedagogical Beliefs and Practices With Regard to Using Technology. Journal of Digital Learning in Teacher Education.

[24] Erdiana, N., Ys, B.S., Akhmal, C.N. (2019). Male vs. female EFL students: Who is better in speaking skill? Studies in English Language and Education, 6(1), 131-140.

[25] Girmen, P., Ozkanal, U., Dayan, G. (2019). Digital Storytelling in the Language Arts Classroom. Universal Journal of Educational Research. 7(1), 55-65.

[26] Gistuati, N., Refnaldi., Syaifullah. (2019). Using Visual Aids to Develop Students' Speaking Skill. Advances in Social Science, Education and Humanities Research, 178, 263-266.

[27] Ho, S. H., (2018).The Effects of Listening Comprehension on ESL Learners' English Language Proficiency. Malaysian Journal of ELT Research, 15(2), 1-16.

[28] Ibrahim, M.A., Khalid, A. (2014). Towards a Digital World: Using Social Networks to Promote Learner's Language. American International Journal of Contemporary Research, $4(10)$.

[29] Izyani, M., Mohamed, A. E. (2016). Students' Perception On The Use Of Whatsapp As A Learning Tool In ESL Classroom. UKM. Journal of Education and Social Sciences, 4, 96-104.

[30] James, P. R. A. P., Yong, K. L., Yunus, M. M. (2019). Hear Me Out! Digital Storytelling to Enhance Speaking Skills. UKM. International Journal of Academic Research in Business and Social Sciences, 9(2), 190-202.

[31] Job, W.M., Abdulkarim, S.M., \& Onesmo, S.N. (2016). WhatsApp Mobile Tool in Second Language Learning: Opportunities, Potentials and Challenges in Higher Education Settings in Tanzania. International Journal of English Language Education, 4(2), 70-90.

[32] Ko, M.H. (2019). Students' reactions to using smartphones and social media for vocabulary feedback. Computer Assisted Language Learning.

[33] Kusmaryani, W., Musthafa, B., Purnawarman, P. (2019). The influence of mobile applications on students' speaking skill and critical thinking in English language learning. Journal of Physics.

[34] Lewis, S.R. (2019). Speaking With Confidence. Cooperative
Extension. 1-39.

[35] Lina, L. (2019). An Exploration of Using Audio Recorded Speaking Tasks with Voice Thread for L2 Oral Proficiency Development. University of New Hampshire, US. IGI Global. 147-165.

[36] Liyana, A.A., Hamid, O.M., Renshaw, P. (2019). Common European framework of reference for languages (CEFR): insights into global policy borrowing in Malaysian higher education. Globalisation, Societies and Education.

[37] Mahardikha, A.P.S., Padmadewi, N.N., Dewi, K.S. (2017), The Effect of Mind Mapping Strategy on the Students' Speaking Competence of Smpn 1 Sukasada. Ganesha Education University.

[38] Menggo, S., Suastra, I.M., Budiarsa, M., Padmadewi, N.N. (2019). Needs Analysis of Academic-English Speaking Material in Promoting 21st Century Skills. International Journal of Instruction, 12(2), 739-754.

[39] Mindari, R., Sriemulyaningsih, M.J.R., Joewono, A. (2016). Developing a Computer-based Interactive Module as Speaking Learning Materials for Primary School Students. International Conference on Education.

[40] MOE. (2017). The Standards-Based Curriculum for Primary Schools. Curriculum Development Centre.

[41] Mona, M.H. (2017). Using WhatsApp to Enhance Students' Learning of English Language "Experience to Share". Higher Education Studies, 7(4), 74-87.

[42] Mustapha, S.M., Rahman, N.S.N.A., Yunus, M.M. (2010). Perceptions towards Classroom Participation: A Case Study of Malaysian Undergraduate Students. In Procedia - Social and Behavioral Sciences. Universiti Kebangsaan Malaysia. (7), 113-121

[43] Mustapha., Maziha, S., Rahman, N.A., Suryani, N., Yunus, M.M. (2010). Factors Influencing Classroom Participation: A Case Study of Malaysian Undergraduate Students. Procedia Social and Behavioral Sciences. Universiti Kebangsaan Malaysia. (9), 1079-1084.

[44] Nanan, A. M. (2017). Whatsapp Mobile Tool In Second Language Learning. Indonesian EFL Journal, 3(1), 87-92.

[45] Nordin, N.M., Hamzaha, M.I., Yunus, M.M., Embia, M.A. (2010). The Mobile Learning Environment for the In-Service School. Procedia Social and Behavioral Sciences, Universiti Kebangsaan Malaysia. 671-679.

[46] Pallavi, M., Sudarshan, M., Neena, D. (2019). Reading Problems of Secondary School Students in English Language. Ravenshaw University India-Odisha.

[47] Parker, R., Thomson, B.S., (2019). Learning through play at school. The LEGO Foundation.

[48] Restu, M., Andi, S. (2016). Establishing a WhatsApp Conversation: One of Innovations in English Language Teaching. 63rd TEFLIN International Conference, 790-796.

[49] Rifati, I.A., Maghfiroh, V.S., Fajrianiii, N., Arumsari, A. (2018). Benefits of Self Confidence in Public Speaking for Students. Airlangga University Surabaya.

[50] Rina, P. (2019). Using Role Play Technique To Improve Students' Speaking. Tanjungpura University. 
[51] Saad, N.S.M., Yunus, M.M., Embi, M.A. (2013). Research on International Students in Traditional Host Countries and Malaysia: Some Potential Areas in Malaysia. Procedia Social and Behavioral Sciences. Universiti Kebangsaan Malaysia. (90), $488-496$.

[52] Saldaria, E., Ariawan, V., Cahyani, I. (2019). Speaking skill of elementary students reviewed by gender. Jurnal Prima Edukasia,7(1), 20-27.

[53] Setiawan, A., Linggar, D.A. (2018). Advances in Social Science, Education and Humanities Research. UNNES International Conference on English Language Teaching, Literature, and Translation. 188, 346-349.

[54] Siti, Z.B.Z., Pillai, S., Francisco, P.D., Phillip, A. (2019). English language and graduate employability. Education + Training. Emerald Insight.

[55] Taslim., Asrifan, A., Chen, Y., NR. N. (2019). Correlation between Student's Vocabulary Mastery and Speaking Skill. Journal of Advanced English Studies, 2(2), 65-76.

[56] Turgay, H., Firat, K. (2016). Using a Mobile Application (WhatsApp) to Reduce EFL Speaking Anxiety. Gist Education and Learning Research Journal. 12, 29-50.
[57] TWC. (2019). Talking With Confidence. Brilliant Workplace Skills for Students \& Graduates. 19-29.

[58] Wahyudi, R., Rukmini, D., Bharati, D.A.L. (2019). Developing Discovery Learning-Based Assessment Module to Stimulate Critical Thinking and Creativity of Students' Speaking Performance. English Education Journal, 9(2), 172-180.

[59] WCLTA. (2010). Procedia Social and Behavioral Sciences, 9, 722-728.

[60] Yoestara, M., Putri, Z. (2018). PODCAST: An alternative way to improve EFL students' listening and speaking performance. Englisia November, 6(1), 15-26.

[61] Yunus, M.M., Hashim, H., Embi, M.A., Lubis, M.A. (2010). The Utilization Of ICT In The Teaching And Learning Of English: "TELL ME MORE." In Procedia - Social and Behavioral Sciences. Universiti Kebangsaan Malaysia. (9), 685-691.

[62] Yunus, M.M., Hashim, H., Mohd. Ishak, N., Mahamod, Z. (2010). Understanding TESL pre-service teacher's teaching experiences and challenges via post-practicum reflection forms. In Procedia - Social and Behavioral Sciences, Universiti Kebangsaan Malaysia. (9), 722-728. 